\title{
The actuarial profession and social security in Brazil from the First Republic up to the Vargas Era
}

\author{
Adelino Martins ${ }^{1}$ \\ (D) https://orcid.org/0000-0002-2076-7132 \\ E-mail: adelinomartins@usp.br
}

1 Universidade de São Paulo, Faculdade de Filosofia, Letras e Ciências Humanas, Programa de Pós-Graduação em História Econômica, São Paulo, SP, Brazil

Received on 11.02.2018 - Desk acceptance on 11.21.2018 - $3^{\text {rd }}$ version approved on 10.31.2019 - Ahead of print on 03.02.2020

Associate Editor: Luís Eduardo Afonso

\begin{abstract}
The aim of this paper was to understand the relationships between the consolidation of the actuarial profession and social security policies in Brazil, from the First Republic up to the Vargas Era. In general, there is little literature on the history of the actuarial profession in Brazil. Specifically, there is no study that addresses the relationship between the development of the actuarial profession and the social security policies at the crucial moment of Brazilian social security expansion during the Vargas Era. This paper contributes to filling that gap. From time to time, Brazilian social security reforms are debated. The role of actuaries in this discussion is poorly understood. However, these professionals have historically been essential to social security policies. This article sheds light on that history. The text may broaden the knowledge on the history of the actuarial profession and its relationships with social security policies in Brazil. This is a historical study, built based on primary documentation. Sources were researched relating to the actuarial organizations for social security in Brazil and the actuarial professionals who composed their staff. The references to the professional trajectories of actuaries were crossed and considered in light of the information gathered regarding the actions of the institutions that employed them. The analysis was qualitative and the material was interpreted with the support of the referenced bibliography. This article reveals that the consolidation of the actuarial profession came about based on the participation of engineers-actuaries in the public organizations that supported the varguista social security policies. The paper also contributes to broadening the knowledge on the history of the actuarial profession in Brazil from the First Republic up to the Vargas Era (1930-1945).
\end{abstract}

Keywords: history of the actuarial profession, social security, actuarial education, Brazilian social security.

Correspondence address

Adelino Martins

Universidade de São Paulo, Faculdade de Filosofia, Letras e Ciências Humanas, Programa de Pós-Graduação em História Econômica

Avenida Professor Lineu Prestes, 338 - CEP 05508-000

Cidade Universitária - São Paulo - SP - Brasil

*Article presented at the 16th National Seminar on History of Science and Technology, Campina Grande, PB, Brazil, October of 2018. 


\section{INTRODUCTION}

As Loyola (2019) notes, in the current discussions on Social Security reform, it is economists, and not actuaries, who play the most prominent role. Seventeen years ago, also in the context of debates on social security, Ramos (2002) complained that the lack of information about actuarial science distorted the objectives and made practicing the profession difficult. Long-lived and barely explored, the history of the relationships between the actuarial profession and social security in Brazil constitutes the object of this article.

The development of the actuarial profession and creation of social security institutions in Brazil were related processes that were crucial in defining the Brazilian actuarial field. The relationships were begun in the First Republic, but gained a new dimension in the Vargas Era (1930-45). During the First Republic, actuarial education was associated with that of accounting professionals, within the scope of technical business education courses. It can be said that, up to the 1920s, more precisely 1923, the field for actuarial activity was limited to private insurance firms. The issuing of the Eloy Chaves Law and creation of the National Labor Council (Conselho Nacional do Trabalho-CNT), an initially consultative collegiate body, constituted the inaugural milestones of the inclusion of actuarial science in the area of social insurance, even if incipiently. The years Getúlio Vargas was in the Catete Palace were ones of expansion of the activities of actuaries in the area of social security, which was given new meaning by the Provisional Government and, above all, by the
Estado Novo (New State). In this paper, it is discussed how the inclusion of actuaries in the State apparatus and their organization into a professional class from the First Republic up to the Vargas Era contributed to the shaping of a social space - a field - dedicated to actuarial science in Brazil. For this, primary documental sources were researched and a historical-sociological approach was elaborated, based on the concepts of field and trajectory, both from the sociology of Pierre Bourdieu. This text communicates the steps and results of the research in four sections, besides this introduction.

The next section carries out a historiographical review of the issue, in order to explain the gap that exists and the type of contribution the paper intends to make to the matter. Next, the historical-sociological approach taken to the subject is discussed, as well as the methodological procedures used during the investigation. The penultimate section presents the research results and is subdivided into three parts: the first discusses the institutional innovation in social security issues promoted by the political regime installed in November of 1930; the second outlines the framework inherited from the First Republic by Getúlio Vargas in terms of the legislation on social insurance and business education; the third discusses the preponderance of engineers in the actuarial services of the institutions responsible for the varguista social security policies and how those professionals led the process of creating the first national actuarial association. The final section contains the conclusions.

\section{HISTORIOGRAPHICAL REVIEW}

The academic production regarding the history of the actuarial profession in Brazil is practically inexistent. The few references available are found in texts on actuarial science teaching, on the development of the private insurance market, and on social security in the country. The situation contrasts sharply with that of England, where modern actuarial science was born.

There is nothing in Brazil resembling History of actuarial profession, by James Hickman (2004), which offers an overview of the history of the actuarial profession from the mid- $19^{\text {th }}$ century to the end of the $20^{\text {th }}$ century, focusing on England and its ex-colonies. The author underlines the importance of 1762 to the history of the actuarial profession, as this was when the Society for Equitable Assurances on Lives and Survivorships was formed. This London-based society provided actuaries with what Hickman (2004) considers fundamental to any profession: a public purpose. In the specific case of the actuarial profession, that was human life assurance.

Alborn (1994) highlighted the importance of the $19^{\text {th }}$ century for English actuaries. He addressed the developments occurring within the London Institute of Actuaries, created in 1848, and the defense that the professionals of the time made not only of their abilities for calculating risks, but, especially, of their judging capacities regarding insurance. The author dealt with the relationships between the life insurance market, the development of actuarial knowledge based on mathematics and statistics, and the analytical capacity of actuaries for the consolidation of the profession in the United Kingdom. 
These relationships between life insurance and the actuarial profession, however, have not been explored in Brazil. Here, although Siqueira (2008) offered a history of insurance in the country between 1808 and 2008, he did not explore the impacts of insurance activity on the establishment of the actuarial profession, on the advancement of actuarial knowledge, and on the training of Brazilian professionals. Attention to the role of actuaries in the operationalization of insurance is, in fact, hard to find even in texts that address the role of technical experts in the development of social insurance policies. When addressing varguista social security policy, both Malloy (1986) and Oliveira and Teixeira (1989) treated these experts as technocrats. They did not, however, specify actuarial technocrats. If fact, it was other professionals who were highlighted by the authors mentioned.

Malloy (1986) underlined the role of lawyers in the technical staff of the Labor Ministry and of the Retirement and Pensions Institute for Industrial Workers (Instituto de Aposentadoria e Pensões dos Industriários - IAPI), the two institutions in which, according to the author, the employment of technical experts was significant. The contributions of the lawyers Arnaldo Sussekind and Moacir Cardoso to varguista social security policy were highlighted. The only engineer-actuary, the type of professional we will focus on, that Malloy (1986) mentioned was João Carlos Vital, who will reappear further on, when we present the research results.

Oliveira and Teixeira (1989) addressed the competent intellectuals, especially those of the IAPI, who played a prominent role in varguista social security policy, but they did not identify them. The authors criticized the "contentionist" character of their actions in the social insurance institutions, with the clear aim of increasing contributions and reducing spending. The social security experts, with their excellent statistical-actuarial training, would have contributed technical implementationary capacity to the political decision to contain spending. Yet, the authors did not explore who the experts were, how they obtained their excellent training, and how they occupied spaces in the federal public administration.

Brazilian actuarial education up to the mid-1940s is the most recurrent aspect in the historiography, even though, as a rule, it appears in a lateral way, in texts dedicated to the training of accountants and economists. It is like that, for example, in the works of Bueno (1972), on the evolution of economic education in the country, of Souza (2006), on the history of the profession of economist in Brazil, of Peleias, Silva, Segreti, and Chirotto (2007), on the evolution of accounting education in Brazil, and of Soares, Richartz, Voss, and Freitas (2011), regarding the evolution of the accounting curriculum in the country since 1809. Bueno (1972) is one of the few authors to explore the fact that engineers pioneered Brazilian public actuarial services.

This article explores how engineers occupied the actuarial positions in social security institutions during the Vargas Era, especially in the Labor Ministry, and how, based on those positions, they contributed decisively to structuring the Brazilian actuarial field. This scenario is also contrasted with the proceeding one of the First Republic.

The next section explains how the research was constructed.

\section{APPROACH AND METHODOLOGICAL PROCEDURES}

This is a historical study informed by the interdisciplinary perspective of the Annales (Reis, 2000). Its starts by identifying a gap - the historical understanding of the relationships between the actuarial profession and social security policy in the first half of the $20^{\text {th }}$ century - and it draws upon inputs from sociology to address it. It involves a qualitative, historical-sociological analysis, which used two concepts from the sociology of Pierre Bourdieu - that of field and that of trajectory.

The concept of field (Bourdieu, 1989, 1996a, 1996b, 2004; Catani, 2011) provides the sense in which the expression actuarial field is employed - a social space composed of standards, organizations, and agents. The latter dispute the possession of the capitals that are relevant there (social, economic, symbolic etc.), that is, of the social resources that enable them to occupy different positions in the field, over their life trajectories. This article deals precisely with a set of standards regarding the social security institutions and actuarial education, as well as the trajectories of actuaries in the organizations in which they worked and associated, especially the Actuarial Department of the Labor Ministry and the Brazilian Institute of Actuarial Science (Instituto Brasileiro de Atuária - IBA).

The actuarial professionals mentioned in this paper occupied different positions in the actuarial organizations linked to social security and developed trajectories that contributed to the formation of their field of activity. The trajectories, however, should not be understood as biographies, in the sense of strands of events essentially 
linked to produce life stories. As Bourdieu (1996a) notes, the notion of trajectory is radically relational, as it assumes the continuous consideration of successive positions occupied by the same agent in a social space subject to transformations.

The methodological procedures were elaborated considering the historiographical approach chosen. The mapping of the organizations and the standards that gave substance to the actuarial field occurred through searching legislative databases - the Official Diary of the Union (Diário Oficial da União - DOU) and the repository of the Chamber of Deputies. There, besides the structures of the actuarial organizations and the arrangements relating to social insurance, information was searched for regarding the actuaries who composed the staff of the bodies that handled social security in Brazil. Having traced the actuarial professionals, information on their intellectual productions, on the positions they occupied in the federal public administration, and on their associative practices were searched for in the DOU, in newspapers from the time, and in the Brazilian Actuarial Journal (Revista Brasileira de Atuária - RBA).

Thus, two documental bodies were collected - one regarding the actuarial services of the social security agencies and social insurance standards and another regarding the actuarial professionals. The data on the professional trajectories derived from various sources were cross-referenced with each other and with the information on the actuarial services, with the aim of identifying their participations in the social security institutions and in their class association. The supporting bibliography was used to provide an understanding of the sources.

\section{RESULTS}

\subsection{The Ministry of the Revolution and the Social Issue}

"The social issue is a case of policing" and the "ministry of the revolution" are two expressions born at times close to each other and that reveal the distance between the approaches taken to labor relations and social security by the First Republic and by the regime inaugurated on November $3^{\text {rd }}$ of 1930 . The first is attributed to the ousted president Washington Luís; the second, to the first head of the Ministry of Labor, Industry, and Commerce, Lindolfo Collor. The latter highlighted the distinctions in his swearing-in ceremony, according to the Jornal do Brasil of December $2^{\text {nd }}$ of 1930 . The minister stated that it was impossible to deny the existence of a social issue in Brazil and expressed the will of the new government to address it on a more liberal and advanced basis than had been done up to then.

Liberal, the adjective employed by the newspaper, would soon be seen not to be the appropriate one for indicating the ideological affiliation of the varguista labor and social security policy. The person that best defined it was Oliveira Vianna (1951): "a state initiative, a generous present from the political leaders - and not a victory for our working masses" (p. 66). A corporativist, Vianna envisioned the pro-worker policies as part of a socially harmonious development program (Vieira, 2010). An intellectual who identified with authoritarian thinking, he collaborated in the "granting" approach to labor and social security issues, as a legal adviser to the Ministry of Labor, Industry, and Commerce, between 1932 and 1940.
The portfolio was one of the first creations of the Provisional Government, instituted by Decree n. 19,433, of November $26^{\text {th }}$ of 1930 . In its structure, the Commercial Statistics Service and the Institute of Social Security and Savings Banks were incorporated, both previously allocated to the Finance Ministry. It would not take long for the ministry's activities to extend to social security. In January of 1931, as communicated by the O Estado de São Paulo newspaper on the $25^{\text {th }}$ of that month, a commission met in Rio de Janeiro to discuss the draft legislative reform involving Retirement and Pension Funds (Caixas de Aposentadorias e Pensões - CAPs), namely Decrees n. 4,682, of January $24^{\text {th }}$ of 1923 , and n. 5,109, of December $20^{\text {th }}$ of 1926 . The 1923 standard became known as the Eloy Chaves Law and created CAPs for railway company workers. The 1926 decree established similar funds for the employees of port and maritime companies. The discussions regarding the reform of social security legislation took almost a year and resulted in the issuing of Decree n. 20,465, of October $31^{\text {st }}$ of 1931, whose first article introduced the following innovations:

I- ON THE ESTABLISHMENT OF RETIREMENT AND PENSION FUNDS.

Art. 1 The public services of transport, light, power, telegraphs, telephones, ports, water, sewerage, or others to be considered as parent, when exploited directly by the Union, by the States, Municipalities, or by companies or groups of companies, will obligatorily have for their employees of different classes or categories, Retirement and Pension Funds, as legal entities, ruled over by the arrangements of this law and directly subordinate to the National Labor Council. 
There is a list of classes or categories that were meant to have funds, which would be subordinate to the CNT. Compared with the legislation that created it in the First Republic, the council saw its respective activities extended to retirement and pension services. According to Malloy (1986), the innovations introduced were not big, but they served to spread the already existing concepts on a systematic basis through an organizational innovation. As of 1933, the CAPs were incorporated into the Institutes of Retirement and Pensions (Institutos de Aposentadorias e Pensões - IAPs), organizations based on professional categories or classes, and not on companies. This contributed to an increase in the number of beneficiaries. Moreover, by defining the funds' sources of financing, the regulation obliged the CAPs to maintain statistical services that were meant to provide elements for actuarial evaluations of their funds and for calculating pensions due. These obligations were subsequently extended to the IAPs.

Actuarial evaluations of the funds, however, were meant to follow the guidelines set out by the CNT, an agency also incorporated into the structure of the Ministry of Labor, Industry, and Commerce. It was established that this council would have normative technical capacity. For that, it would be necessary to have staff and a structure capable of handling actuarial calculations and projections. That was the point at which the social security policies, central to establishing Vargas' ties with the various professional categories, especially in the Provisional Government and during the Estado Novo, encountered the need for actuarial services and actuaries. Who, after all, would provide this council with the technical support to issue guidelines? Decree n. 24,747, of July $14^{\text {th }}$ of 1934 , created the technical body responsible for the service - the Actuarial Department of the Labor Ministry. Decree n. 24,748 , also of July $14^{\text {th }}$ of 1934 , established the following regulation:

Art. 1 The Actuarial Department of the Ministry of Labor, Industry, and Commerce, created by decree n. 24,748, of July $14^{\text {th }}$ of 1934 , is a specialized technical body, governed by the present regulation, and geared toward the general supervision of the actuarial services of the National Labor Council, of the departments, institutes, and other divisions subordinate to the Ministry of Labor, Industry, and Commerce, as well as helping the government in studying all the applications of the actuarial technique.

It can therefore be seen that the materialization of the attributions of the CNT depended on the actuarial department, which contributed to the organization, management, and execution of actuarial services within the Ministry of Labor, Industry, and Commerce. This included studying, in technical bases, mortality and invalidity tables, salary scales, statistics, and actuarial information. For this, the body had to have, in its structure, in the terms of its regulations, an actuarial council, a collegiate body that was deliberative and advisory in nature, a technical-administrative service, and another technical-actuarial one.

Among other things, it was the responsibility of the Actuarial Council of the Actuarial Department to answer consultations of a technical nature that were sent to it from other sectors of the Labor Ministry and, also, by the Legislative and Executive powers. Article 12, item "d", of Decree n. 4,748 , of July $14^{\text {th }}$ of 1934 , attributed to the actuarial council the competence of "organizing regulatory projects and instructions that the Government has to issue regarding technical actuarial subjects, having heard the interested divisions, and giving an opinion on projects organized by the same divisions and relating to the same subject." With this, in practice, the normative responsibilities of the CNT with relation to social security came to depend on the Actuarial Council of the Actuarial Department of the Labor Ministry.

As if all these responsibilities were not enough, the actuarial department was also charged with organizing and maintaining a specialized journal for publishing the deliberations and opinions expressed by the body, as well as reviews and papers signed by the actuaries belonging to the institution's staff or by others, from outside, but that presented contributions of notable value.

And this is where one difficulty with regard to carrying out the social security policy of the Labor Ministry can be found. If, in order to conceive the actuarial institutions, discussions, paper, and ink were enough, in order to make them concrete, much more would be needed. Where would actuaries of outstanding value be found? How would they be recruited for the positions of heads, assistants, and deputies created by article 4 of the Actuarial Department Regulation? To give an idea of the size of the challenge, it should be borne in mind that the degree courses in actuarial sciences only came into existence after Law n. 1,401 , of July $31^{\text {st }}$ of 1951 . Up until then, actuarial science was associated with accounting in higher education and this situation was recent, since it dated back to DecreeLaw n. 7.988, of September $22^{\text {nd }}$ of 1945 . Up until 1945, training only occurred at commercial-technical schools.

Between the start of the 1930s and the mid-1940s, therefore, the actuarial department faced the challenge of recruiting specialized personnel. The training of expert accountants and actuaries took place in business courses, whose organization, established by Decree n. 20,158, of June $30^{\text {th }}$ of 1931, was contemporaneous to the legislative 
reform of CAPs. This involved a technical course lasting six years. In the first three, there were propaedeutic disciplines such as Portuguese, English, French, mathematics, physics, and history; in the final three, a qualification would be chosen. If the actuarial course was chosen, commercial and insurance accounting, commercial and financial mathematics, actuarial calculus, and general statistics and statistics applied to actuarial science would be studied. Holders of the technical diploma in actuarial science could gain access to the degree course in business and finance.

As can be seen, actuarial education completely lacked any in-depth investigation into the actuarial and statistical disciplines, offered only in the final year of the technical courses. However, students of these courses, according to article 79 of the decree on the organization of business education, were meant to occupy the technical actuarial positions in the credit and social security institutions of the Union, the states, and the municipalities. The situation was particularly contradictory for the actuarial department. Created in July of 1934, its staff was meant to be composed of technicians who had passed a public exam, which would require proficiency in differential calculus, actuarial science, statistics and probabilities, insurance legislation, and the organization of CAPs. However, obtaining such knowledge was to a large extent supposed to rely on the candidates' personal effort, as the curriculum of the technical course in actuarial science did not contemplate some of those subjects and did not dedicate much time to others.

With that difficulty in mind, one absence and one possibility can be highlighted in the Actuarial Department Regulation. Regarding the absence, the standard made it obligatory for public exams to be sat to fill the actuarial positions, but it did not reserve them for graduates from technical courses in actuarial sciences. The positions were filled, above all, by engineers originating from the Polytechnic School of Rio de Janeiro, solidly trained in calculus and competent in statistics, subjects they had studied since the $19^{\text {th }}$ century, in association with political economy and business law (Moreira, 2014). Regarding the possibility, the regulation allowed for foreign technicians of outstanding value and capacity to be hired.

The possibility was used. On June $21^{\text {st }}$ of 1932 , the Labor Ministry (Official Diary of the Union [DOU], 1932) designated the actuaries Clodoveu de Oliveira, Paulo Leopoldo P. da Câmara, and Maurice Gauthier to compose the commission meant to issue an opinion regarding the creation of the Retirement and Pension Fund for Maritime Workers, the future Retirement and Pensions Institute for Maritime Workers (Instituto de Aposentadoria e Pensões dos Marítimos - IAPM). Clodoveu de Oliveira and Paulo Leopoldo were engineers and would soon occupy positions in the Actuarial Department of the Labor
Ministry and take part in organizing their professional class. Maurice Gauthier, also an engineer, was a member of the Institute of French Actuaries. Affiliated with the Paris Statistics Society since 1928, he arrived in Brazil a few years later, employed by Companhia de Seguros SulAmérica (South America Insurance Company) (Société de Statistique de Paris, 1961).

In April of 1932, before being appointed to the commission for creating the IAPM, Gauthier presented the thesis "Accounting for life insurance and capitalization companies" to the Second Brazilian Congress on Accounting. There, he emphasized the specific nature of insurance contacts, which according to him were more complex than ordinary long-term accounting operations, as they involved lifetime and temporary incomes foreseen in plans backed by mathematical reserves, which he defined as the "difference between the commitments of the insurer and of the insured. The reserves calculation is made using formulas subject to a special technique, actuarial science" (1932, p. 160).

Yet the concern about actuarial science was not exclusive to one French actuary in Brazil. It had already appeared at the First Brazilian Congress on Accounting, organized in 1924, one year after the creation of the CNT. At that meeting, Augusto Carlos de Setubal, one of its promoters and an enthusiast for regulating accounting education and the accounting profession in Brazil, recognized the convenience of the spread of insurance companies, since "the more widespread the activities of these institutions are, the lower the task of public assistance will be" (Setubal, 1927, p. 329), but he urged the government to organize the sector by ensuring that official actuaries examined aid tables being examined by official actuaries.

Between Setubal's text, presented in 1924 and published in 1927, and the Decree that created the Actuarial Department of the Labor Ministry, in 1934, it can be affirmed that there was an advance in the arrangements regarding the training of actuaries, as well as in their employment in actuarial services for social security. The creation of an actuarial department to support the work of the CNT and the existence of a technical course in actuarial science within business education exemplify that. The framework inherited from the First Republic, characterized by incipient social security legislation, which barely mentioned actuarial professionals, thus underwent significant modifications.

\subsection{The Legacy of the First Republic}

The first republican standard regarding insurance, Decree n. 294, of 1895, was meant solely for the securitization of lives provided by foreign private companies. It focused on the need to publish guaranteed 
insurance and determined the employment of reserves for all policies in national securities, whether real estate or railway stocks. In 1901, a more comprehensive regulation was issued by the Finance Minister Joaquim Murtinho, via Decree n. 4,270 , of December $10^{\text {th }}$ of 1901 , which created the General Superintendence of Insurance, later the Insurance Inspectorate, and established the rules for monitoring all insurance activity in Brazil. In the long rule, however, there is no more than one mention of actuaries, in article 160, to determine that they should be employed to verify that the reserves that cover policies were, in fact, invested in national securities.

If, for private insurance, the precariousness of the reference to actuaries would suggest the weakness of the supervision of investment of the reserve values of policies in national securities, for social insurance, the deficiency in the legislation was greater. The composition of the CNT, created by Decree n. 16,027, of April $30^{\text {th }}$ of 1923, did not even mention the figure of actuarial professional. Article 7 of the text foresaw the existence of a generic expert in subjects pertaining to the council, which included a vast amount of social security material, as can be read in article 2 (Decree n. 16,027, of April 30 ${ }^{\text {th }}$ of 1923):

Art. 2 Besides studying other matters that may be of interest to the organization of labor and social security, the National Labor Council will be responsible for the following: normal working days in the main industries, job remuneration systems, collective labor contracts, reconciliation and arbitrage systems, especially to prevent or resolve disputes, child labor, female labor, technical teaching and learning, accidents at work, social insurance; retirement and pension funds for rail workers, popular credit institutions, and agricultural credit providers.

Actuarial professionals were also not mentioned in the legislation that described CAPs. Their absence, besides being symptomatic of the scarcity of professionals in the area and the poor understanding regarding the scope of their work, indicated the limited materialization of the actuarial attributions reserved for the funds and the CNT. It was only after the fall of the First Republic that these issues were addressed in the sense of rationalizing the training of the professionals and their systematic employment in social security services, which then extended social security cover in the urban environment.

In effect, during the Vargas Era, there was a systematic advancement toward establishing an institutional framework for social security, incorporating actuarial professionals into it. This framework was composed of the Ministry of Labor, Industry, and Commerce and of its actuarial department, by the legislative reform of the CAPs, by the creation of the IAPs, and by the issuing of Decree n. 20,158, of June $30^{\text {th }}$ of 1931, which established an official curriculum for technical courses in actuarial science.

Up until then, the legislation on commercial education had barely discussed the training of actuaries. The Republic had inherited from the Empire the erratic training of professionals who dealt with actuarial issues and commercial statistics. In São Paulo, as of 1886, Mackenzie College started to offer a Degree Course in Commerce (Garcez, 2004) that, if it did not train actuarial professionals specifically, prepared students to carry out commercial functions. Under the pretense that it was unattractive, however, the course was transformed into a commercial-technical one. In Rio de Janeiro, the experience with the training of accountants, actuaries, and bookkeepers was older, but suffered from discontinuity. In 1856, the Commercial Institute was created to support the Business Class, established in 1846. The school offered, among other disciplines, commercial statistics, but was closed in 1882, with a similar excuse to that of the conversion of the course at Mackenzie College years later: a lack of students.

Only with the Republic did systematic treatment of the training of accountants, actuaries, and economists begin to be established. In 1905, Decree n. 1,339, of January $9^{\text {th }}$, recognized as a public utility the Commercial Academy of Rio de Janeiro and, consequently, the diplomas it issued. The norm foresaw the offer of a general course and a degree one. The first would train individuals to practice the role of bookkeepers and prepare them to join the second. This, in turn, would train actuarial professionals and heads of accounting. The same legal regime was extended to the São Paulo School of Commerce, which, just like the Rio academy, had operated since 1902. The disciplines of the degree course, which mixed diplomatic correspondence and statistics, were as varied as the qualifications foreseen were diverse (Decree n. 1,339, of January $9^{\text {th }}$ of 1905 , art. $1^{\circ}, \$ 1^{\circ}$ ): "consular agents, employees of the Ministry of Foreign Relations, actuaries of insurance firms, and heads of accounting of banking establishments and large commercial enterprises."

It was that decree that provided the curricular basis for the training of business professionals, including actuaries, up to 1926. Basically, as Bueno (1972) noted, it established the Rio de Janeiro Academy of Commerce course as an official standard for business education in the country. Between 1905 and 1926, especially in Rio de Janeiro and São Paulo, a core group of accountants was developed that started to fight for the recognition of the profession and the regulation of business teaching. They engaged in efforts to reorganize accounting services and for economic-budgetary streamlining of the State, 
occupying important positions in the Central Account Office of the Republic, in the case of Francisco D'Áuria, and in the Finance Ministry, such as by João Ferreira de Moraes Junior. In exchange, they requested teaching and professional legislation in accordance with their concerns. During the four-year tenure of Arthur Bernardes, the president repeatedly commended the accounting services provided to his management (Bernardes, 1924).

As retribution, delegations of accountants were heard when the issuing of legislation on business teaching was discussed, under the coordination of the Ministry of Agriculture, Industry, and Commerce. The June 1925 edition of the São Paulo Accounting Journal (Revista Paulista de Contabilidade - Instituto Paulista de Contabilidade, 1925) highlighted the participation of a group sent by the Álvares Penteado School of Commerce to present, in May of the same year, its contribution to the proposed regulation. Decree n. 17,329, of May $28^{\text {th }}$ of 1926, which discussed commercial-technical teaching, was the arrangement resulting from the negotiations and incorporated proposals from the accountants. The standard created a degree course in economics, it established the curriculum for commercial-technical teaching, and it gave the teaching establishments recognized by the federal government the possibility of offering specializations in actuarial science and accounts inspection without, however, specifying the curriculum for them. The mention of actuarial science was limited to a single paragraph of article 3 (Decree n. 17,329, of May $28^{\text {th }}$ of 1926): "the establishments can also have specialization courses geared toward particular professions (actuarial, consular, accounts inspection, etc.)."

This changed the panorama for actuarial professionals. Decree n. 1,339, of January $9^{\text {th }}$ of 1905 , foresaw that the degree course would be responsible for training them. On the other hand, Decree n. 17,329, of May $28^{\text {th }}$ of 1926, reserved the degree to the economics course. The curriculum of that course, in turn, although it contemplated mathematics applied to commercial operations and finance, did not contain any discipline relating to actuarial science (Decree n. 17,329, of May $28^{\text {th }}$ of 1926). Actuarial training would be carried out in specialization courses after graduation that may or may not be offered by business education schools.

The First Republic therefore left to the government installed in November of 1930 a disperse framework regarding the training of actuaries and their actuation in the field of social security. It was precisely the new regime's interest in labor and social security issues that triggered the alterations in the employment of actuarial professionals in the structure of the Brazilian State. The legislation and diffusion of teaching in the area, despite not having accompanied the rhythm of the alterations produced by the inclusion of actuaries in the State apparatus, especially in the Labor Ministry, also received an impulse.

\subsection{Engineers and Social Security. The Actuarial Department of the Labor Ministry}

The business education legislation was reformed by Decree n. 20,158, of June $30^{\text {th }}$ of 1931 , and later altered by Decree n. 21,033, of February $8^{\text {th }}$ of 1932 . The modification was elaborated, however, by the Education Ministry without the same kind of involvement that the accountants had in 1926. For the first time, actuarial education received its own curriculum. Of the six years of training, three propaedeutic and three technical, the specific materials of actuarial science and statistics were concentrated in the final one (Decree n. 20,158, of June $30^{\text {th }}$ of 1931):

Art. 6 - The disciplines of the technical courses will be distributed as follows:

d) Actuarial Course. Third year: 1) Insurance accounting: Orientation as with the other accounting fields, but in relation to an insurance company; 2) Actuarial calculus: Statistics and demographics. Calculation of probabilities. Survival and mortality. Lifetime incomes. Use and ownership of securities. Actuarial notations. Commutation tables. Life insurance. Technical reserve; 3) Insurance legislation: Interpretation of legal texts and their application. Practical cases; 4) Statistics: In general and their application to actuarial sciences.

Yet, it was not enough. The scarcity of actuaries persisted. There was legal provision for the training of technicians, but the reality continued without enough professionals being trained. The regulations themselves issued by the Provisional Government confirmed this. Article 74 of Decree n. 20,158, of June $30^{\text {th }}$ of 1931 , determined the presentation of diplomas foreseen there so that the professionals could assume positions as actuaries in insurance companies and occupy public posts that required accounting knowledge. Yet, in 1933, the execution of the arrangement was suspended for nine months; in 1934, for one year. The reasons were given by Decree n. 22,382, of January $23^{\text {rd }}$ of 1933 : "deficiency of professionals qualified in the conditions required for enrollment in public exams geared toward immediately filling a high number of posts."

Besides being quantitatively scarce, actuarial technicians suffered from insufficiencies in their training. As seen, they only studied specifically actuarial and statistical contents in the final year of their courses. Included in the efforts to streamline the bureaucracy of sectors of the federal 
government machine, the Actuarial Department of the Labor Ministry, in compliance with Decree n. 24,748, of July $14^{\text {th }}$ of 1934 , recruited their staff through rigorous public exams, which included the previous establishment of the good character of the candidates and were also of a practical nature, focusing on calculations, statistics, and probabilities. In these exams, those who passed were not actuarial technicians. Those occupying the positions in the Actuarial Department of the Labor Ministry were mostly engineers, professionals with solid traditional training in mathematics and statistics, originating from military and polytechnic schools, and thus graduates from degree courses, something that actuaries would only achieve after 1945. As Bueno (1972) noted, the Polytechnic School of Rio de Janeiro, for example, had since 1890 let engineering students study mortality tables, amortizations by the price system, and Tontine company calculations, in their mathematics course.

This provoked discussions regarding the organization of the actuarial class in an association, an important step in the formation of the field of actuarial science in Brazil. In the minutes of the formation proceedings of the IBA, occurring on September $14^{\text {th }}$ of 1944 , at the headquarters of the Brazilian Reinsurance Institute (Instituto de Resseguros do Brasil - IRB), it is reported that five people, who refused to give their names, presented themselves as qualified actuaries and, with that status, demanded to take part in the debates on the statutes of the association concerned. The assembly accepted and Eduardo Guidão da Cruz, secretary of the meeting, bequeathed us the record, published in the DOU of December $9^{\text {th }}$ of 1944 , p. 20,729:

Having reinitiated the reading and debate on the Statutes, the same person who before had done so claiming the quality of qualified actuary, repeatedly asked to speak to go over the same argument, namely, that those holding that title should be admitted to the Institute. Many times the board explained to the aforementioned person that a civil society is allowed to, at its own criterion, choose its founders and set the rules for the subsequent submission of members.

The actuaries' protest is significant of the history of the correlation of forces in the professional field that was being designed. Diploma holders in actuarial science existed, trained by technical courses, but they were not given leadership in the process of forming the first national association for the category, this instead going to engineers. These, in the official publications of the federal actuarial services, were referred to as actuaries. In fact, in the Actuarial Department of the Labor Ministry and in IRB they were the actuaries and extended their leadership from that sphere to the association, running the process for forming the IBA. So, it made no sense to limit access to the institute, at that time, to those qualified in technical courses in actuarial science. The way spaces were occupied in the actuarial department was replicated in the IBA.

Guidão da Cruz, secretary of the birth certificate of the institute, was described as an engineer and actuary of the Labor Ministry. He was secretary at a meeting opened by the civil engineer João Carlos Vital, someone with an extensive list of services provided to the federal government. President of IRB between 1939 and 1946, he was director-general of Statistics and Advertising of the Labor Ministry, president of the commission that organized the IAPI, interim minister of Labor, and mayor of Rio de Janeiro between 1951 and 1952 (Abreu, 2001). After opening the proceedings, Vital nominated professor Abrahão Izecksohn, an engineer who had served as an actuary of the Labor Ministry until assuming the thermodynamics chair of the National School of Engineering in 1940 (DOU, 1940), to lead the efforts to approve the statute and choose the management of the association.

In fact, the assembly for creating the IBA included various engineers who contributed to varguista social security policy. Two warrant mentioning. First, Clodoveu de Oliveira (Almanak Laemmert, 1934; DOU, 1936, 1937, 1939; Gomes, 2007), trained at the School of Engineering of Ouro Preto and a longstanding labor militant, took part in the elaboration of the decree that created the Employment and Social Security Booklet, he wrote a book on accidents at work (D'Oliveira \& Tullio, 1935), and he was head actuary and president of the Actuarial Council of the Actuarial Department of the Labor Ministry. Second, Lino Leal de Sá Pereira was the first president of the IBA, a professor of the National School of Engineering, and he headed the Institute of Social Welfare and Assistance for Servants of the State in 1941 (DOU, 1939, 1941, 1949). Carreiro (1948) attributed to him the construction of the INP (Instituto Nacional de Previdência - National Social Security Institute) general mortality table, up to then usually employed in evaluating social security in Brazil.

Moreover, all the actuary members of the Actuarial Department of the Labor Ministry (1942) signed the agreement that founded the IBA in 1944. Table 1 presents them. 
Table 1

Members of the actuarial department (1942), engineers, and founders of the Brazilian Actuarial Institute (IBA) in 1944

\begin{tabular}{|c|c|}
\hline Engineer & Professional experiences chosen \\
\hline $\begin{array}{l}\text { Gastão Quartin } \\
\text { Pinto de Moura }\end{array}$ & $\begin{array}{l}\text { Actuarial assistant on the National Labor Council (CNT) (1933); took part in the Regulation Commission of the Institute } \\
\text { of Retirement and Pensions for Bank Workers (1934); head of the Actuarial Technical Service of the CNT (1939); director } \\
\text { of the Statistics Service for Social Security (1950), adviser of the National Department of Social Security (1959). }\end{array}$ \\
\hline $\begin{array}{l}\text { Eduardo Guidão } \\
\text { da Cruz }\end{array}$ & $\begin{array}{l}\text { Presided over the special commission that presented the draft project on contributions transfers between Retirement and } \\
\text { Pension Funds (1939). }\end{array}$ \\
\hline $\begin{array}{l}\text { Paulo Leopoldo P. } \\
\text { da Câmara }\end{array}$ & President of the Actuarial Council of the Labor Ministry. \\
\hline $\begin{array}{l}\text { Carlos Augusto } \\
\text { Leal Jourdan }\end{array}$ & Deputy actuary of the actuarial department; adviser of the National Department of Social Security (1959). \\
\hline João Lyra Madeira & $\begin{array}{l}\text { Actuarial assistant at the CNT (1939); worked on the work uniformization commission of the National Department of } \\
\text { Labor (1935) and on the commission for studying the issue of average assistance to associates of the social security } \\
\text { institutions (1941). }\end{array}$ \\
\hline $\begin{array}{l}\text { Frederico José de } \\
\text { S. Rangel }\end{array}$ & Head actuary of the National Department of Private Capitalization Insurance, actuary at the actuarial department. \\
\hline $\begin{array}{l}\text { Plínio Reis de } \\
\text { Catanhede }\end{array}$ & Head actuary at the National Department of Labor. \\
\hline $\begin{array}{l}\text { Emílio de Souza } \\
\text { Pereira }\end{array}$ & Delegate from Brazil at the II Interamerican Congress on Social Security, Chile, 1942. \\
\hline $\begin{array}{l}\text { Júlio de Barros } \\
\text { Barreto }\end{array}$ & Actuary designated to work on the organization of the Industrial Workers Retirement Institute (IAPI). \\
\hline $\begin{array}{l}\text { Oscar Porto } \\
\text { Carreiro }\end{array}$ & Deputy actuary; professor at the National School of Engineering. \\
\hline $\begin{array}{l}\text { Manoel Nogueira } \\
\text { de Paula }\end{array}$ & President of the Permanent Commission on Actuarial Service Fees of the National Department of Labor. \\
\hline $\begin{array}{l}\text { Jerônimo José de } \\
\text { Mesquita }\end{array}$ & Head of the Actuarial-Technical Service of the National Department of Labor. \\
\hline Sylvio Pinto Lopes & Worked on the Permanent Commission on Actuarial Service Fees of the National Department of Labor. \\
\hline
\end{tabular}

Note: The composition of the actuarial department is the one informed by the Brazilian Actuarial Journal ("Revista Brasileira de Atuária") (1942, 1(4), 75). The sources that provided the information on the professional trajectories are the following: for Eduardo Guidão da Cruz, Official Diary of the Union (DOU) of 6/10/1935, 7/4/1935, 12/27/1935, and of 11/22/1940; for Gastão Quartin Pinto de Moura, DOU of 9/12/1939, 10/20/1951, and 11/28/1951 and "Correio da Manhã" of 3/31/1933; for João Lyra Madeira, DOU of 3/3/1933, 9/17/1935, 10/16/1935, and 6/12/1941; for Paulo Leopoldo P. da Câmara, DOU of 8/21/1939 and RBA of 1941; for Carlos Augusto Leal Jourdan, DOU of 6/10/1935 and 12/14/1959; for Frederico José de S. Rangel, DOU of 11/9/1935 and RBA of 1941; for Plínio Reis de Catanhede, DOU of 9/4/1934 and of 11/21/1935; for Emílio de Souza Pereira, DOU of 9/8/1942 and of 9/9/1942; for Gilberto Lyra da Silva, DOU of 1/14/1936; for Júlio de Barros Barreto, DOU of 3/27/1939; for Oscar Porto Carreiro, DOU of 1/14/1936 and of 3/15/1938; for Manoel Nogueira de Paula, DOU of 2/13/1943.

Source: Elaborated by the author.

The two names that are missing to complete the staff of the Actuarial Department of the Labor Ministry of 1942 are Renato de Castro and Gilberto Lyra da Silva, the only ones for whom no records of them being engineers were found. It is noted that, of the names listed in the table, Gastão Quartin Pinto de Moura, João Lyra Madeira, Paulo Leopoldo P. da Câmara, and Carlos Augusto Leal Jourdan were successors of Lino Leal in the presidency of the IBA.

The composition of that institution is, therefore, a favorable viewpoint for analyzing the formation of the field of activities of Brazilian actuaries. They were mostly engineers; they were included in the structure of the State, above all in the Actuarial Department of the Labor Ministry, from where they contributed to the creation of the IAPs and produced the journal that made clear the importance of the public social security sector in the consolidation of the actuarial profession in Brazil.

The RBA was foreseen in Decree n. 24,747, of July $14^{\text {th }}$ of 1934 , which created the actuarial department. However, seven years were needed for the publication to come to light. Quarterly, its first edition came out in April of 1941, with an introduction by Getúlio Vargas. There he recognized the essential nature of the actuarial technique for social security and called the champions of Brazilian actuarial science collaborators in the social well-being of Brazil. In effect, they corroborated technically in the construction of the "work-benefit" logic, characteristic of the president's social policy (Gomes, 2005). Also in the 
introduction of the first volume of the journal, Clodoveu de Oliveira provided clues that the engineers-actuaries were aware of the political framework their work fit into. For him, the professionals of the area endeavored to shield human weakness from misfortune, but they were scarce (D’Oliveira, 1941, p. 5): "quantitatively very reduced, perhaps numerically the fewest of the classes." There were also not many covered by the social protection they designed. Limited to urban workers, it reached the rural environment and that of domestic workers only at the start of the 1970s (Hochman \& Fonseca, 1999).

The small group, however, was prolific on the pages of the journal. There, besides the opinions issued by the actuarial council and the minutes of their meetings, technical articles were present, as well as the translation of the Beveridge report on social security for Great Britain in the post-war period (Actuarial Department of the Labor Ministry, 1943). In volume 4 (Brazilian Actuarial Institute, 1944-1945), the assembly for forming the IBA was reported and the text of its statute was reproduced. The creation of the institute was presented as a longstanding aspiration of actuaries, realized thanks to the initiative of the organizing commission, composed of Eduardo Guidão da Cruz, Gastão Quartin Pinto de Moura, João Lyra Madeira, René Celéstin Scholastique, Victor Gulzgoff, and Frederico José de S. Rangel. Of the organizing commission, only Vitor Gulzgoff and René Celestin Scholastique, head actuary of Companhia Sul América de Seguros and future president of the IBA, did not belong to the Actuarial Department of the Labor Ministry.

The realization of this aspiration was followed by a period of advances. In 1945, actuarial education was raised to the status of a degree course in accounting and actuarial sciences. In 1951, actuarial science completed a movement started in the 1930s and 1940s and dissociated from the accounting course, forming its own bachelor's degree. Although it continued to share institutional spaces and engage in dialogue with accounting sciences, it was brought closer and closer to statistics and mathematics. An example of this is the contribution that Oscar Edivaldo Porto Carreiro, an engineer, member of the actuarial department, and subsequently professor at the National School of Engineering, offered the journal of the Brazilian Institute of Geography and Statistics (IBGE). In the article, "Statistics and actuarial science" (Carreiro, 1948, p. 357), he stated that the particularity of insurance contracts, which set premiums to be paid if there is the occurrence of random events, brought the two fields of knowledge closer together:

\begin{abstract}
Actuarial problems derive from a "sui generis" contract in which the contracting parties assume commitments to pay if random facts occur. These facts may be the result of luck, the life or the death of individuals, invalidity, illness, an accident at work; they may be fire, a shipwreck, theft, damage to third parties, or freezing. But they should be causal; and as chance only shows regularity if the number of events is high, it is necessary for random experiences characteristic of the contract to repeat many times, at least for one of the contracting parties - the insurer. It is from this singularity of the contract that, as will be seen below, the relationships between statistics and actuarial science result.
\end{abstract}

Another advance subsequent to 1945 was the issuing of Decree-Law n. 806, of September $4^{\text {th }}$ of 1969 . The rule regulated professional actuarial practice, reserving to actuaries, in article 5, the posts of the Actuarial Service of the Labor Ministry.

If, at the start of the 1930s, therefore, the profession and training of actuaries were treated within the legislation on business education and the accounting profession, the engagement of engineers in social security activities throughout the Vargas Era modified that framework. Engineers-actuaries were absorbed by the organizations responsible for varguista social security policy and, in parallel to that occupation of spaces, they led the formation of the IBA. Through the pages of the RBA, in which they published studies and opinions, they contributed to spreading actuarial knowledge and to setting the specific technical profile of actuaries, which required statistical knowledge. After all, retirements and pensions required life and invalidity tables based on population censuses and complex probabilistic analyses.

Therefore, the development of the actuarial profession in Brazil, from 1930 to 1945, went pari passu with the formation of the institutional framework for social security in the country. The process occurred through the action taken by engineers, professionals whose trajectories through the federal actuarial services, especially the Actuarial Department of the Labor Ministry, were essential in organizing the social space for the activities of Brazilian actuaries.

\section{CONCLUSION}

From sparse references in regulations relating to private insurance and to Retirement Funds in the First
Republic, after the 1930s actuarial science marched toward the consolidation of a professional and academic field. 
This path involved engineering and social security. If economists, and not actuaries, have occupied a key role in the discussions on social security reform in Brazil since the end of the $20^{\text {th }}$ century, it was engineers who were technically prominent in the expansion of social security in Brazil throughout the Vargas Era. They were the actuaries of the State.

The regime inaugurated in 1930 gave another dimension to the social issue. Labor relations and social security were prioritized, especially in the Provisional Government and in the Estado Novo dictatorship, as a form of political legitimization. In order to have social security material available, regulations, a bureaucratic structure, and personnel were needed. The first two were provided by the social security legislative reform and by the creation of the Actuarial Department of the Labor Ministry and of the IAPs. Regarding personnel, the actuarial posts were mostly occupied by engineers, degree-level professionals with more solid training in mathematics and statistics than the students of technical courses in actuarial science. The engineers-actuaries organized a journal, created the first national association for the Brazilian actuarial class, and, gradually, set the foundations for actuarial science in the country.

At the end of the Vargas Era, the social field of activity of actuaries had gained density. The space of these professionals was consolidated inside the social security services, there was a national class association, and actuarial education was raised to the status of a degree course. Not all was achieved, however. It would still take 25 years for the State to regulate the professional practice.

\section{REFERENCES}

Abreu, A. A. (coord.). (2001). Dicionário histórico biográfico brasileiro pós-1930 ( $2^{\text {nd }}$ ed.). Rio de Janeiro, RJ: Editora da Fundação Getúlio Vargas.

Actos do Chefe do Governo Provisório (Acts of the Head of the Provisional Government). Decrees in the portfolios of Justice, Labor, and the Treasury. (1933, March $31^{\text {st }}$ ). Correio da Manhã. Retrieved from http://memoria.bn.br/ DocReader/docreader.aspx?bib=089842_04\&pasta=ano\%20 193\&pesq=quartin

Alborn, T. (1994). A calculating profession: Victorian actuaries among the statisticians. In M. Power, Accounting and science: Natural inquiry and commercial reason. Cambridge: Cambridge University Press.

Almanak Laemmert (1934). Anuário comercial, industrial, profissional, administrativo, de estatística e informações gerais do Brasil. Retrieved from http://hemerotecadigital.bn.br/ acervo-digital/almanak-administrativo-mercantil-industrialrio-janeiro/313394

Atuariado do Ministério do Trabalho (Actuarial Department of the Labor Ministry). (1942). Administrative organization of the actuarial department. Revista Brasileira de Atuária, 1(4), 75.

Atuariado do Ministério do Trabalho (Actuarial Department of the Labor Ministry). (1943). Plans for social security in Great Britain. Revista Brasileira de Atuária, 2(4), 69-92.

Bernardes, A. (1924). Mensagem presidencial apresentada ao Congresso Nacional. Retrieved from http://www-apps.crl.edu/ brazil/presidential.

Bourdieu, P. (1989). O poder simbólico. Lisboa: Difel; São Paulo, SP: Bertrand Brasil.

Bourdieu, P. (1996a). A ilusão biográfica. In M. Ferreira \& J. Amado (Orgs.). Usos e abusos da história oral. Rio de Janeiro, RJ: Editora da Fundação Getúlio Vargas.

Bourdieu, P. (1996b). Razões práticas: sobre a teoria da ação. Campinas, SP: Papirus.
Bourdieu, P. (2004). Questões de sociologia. Lisboa: Fim de Século.

Bueno, L. de F. (1972). A evolução do ensino de economia no Brasil. Retrieved from http://bibliotecadigital.fgv. br/dspace/bitstream/handle/10438/688/000348879. pdf? sequence $=1$ \&isAllowed $=y$

Carreiro, O. P. (1948). A estatística e a atuária. Revista Brasileira de Estatística, 1(35), 357-372.

Catani, A. M. (2011). As possibilidades analíticas da noção de campo social. Educação \& Sociedade, 32(114), 189-202.

D’Oliveira, C. (1941). A Revista Brasileira de Atuária e seus fins Revista Brasileira de Atuária, 1(1), 4-6.

D’Oliveira, C., \& Tullio, C. (1935). Acidentes de trabalho. Rio de Janeiro, RJ: Coelho Branco.

Decree n. 1,339. (1905, January 9 $\left.9^{\text {th }}\right)$. Declares the Academy of Commerce of Rio the Janeiro is an institution of public utility, recognizes the diplomas issued by it as being official, and makes other arrangements. Retrieved from https://www2. camara.leg.br/legin/fed/decret/1900-1909/decreto-1339-9janeiro-1905-612623-publicacaooriginal-135659-pl.html

Decree $n .16,027$. (1923, April 30 $\left.{ }^{\text {th }}\right)$. Creates the National Labor Council. Retrieved from https://www2.camara.leg.br/legin/ fed/decret/1920-1929/decreto-16027-30-abril-1923-566906publicacaooriginal-90409-pe.html

Decree $n$. 17,329. (1926, May $\left.28^{\text {th }}\right)$. Approves the regulation for the technical-business education establishments officially recognized by the Federal Government. Retrieved from https:// www2.camara.leg.br/legin/fed/decret/1920-1929/decreto17329-28-maio-1926-514068-republicacao-88142-pe.html

Degree $n .19,433$. (1930, November $\left.26^{\text {th }}\right)$. Creates a State Secretariate with the denomination of Ministry of Labor, Industry, and Commerce. Retrieved from https://www2. camara.leg.br/legin/fed/decret/1930-1939/decreto-19433-26novembro-1930-517354-publicacaooriginal-1-pe.html

Decree n. 20,158. (1931, June $\left.30^{\text {th }}\right)$. Organizes business education, regulates the profession of accountant, and makes other 
arrangements. Retrieved from https://www2.camara.leg.br/ legin/fed/decret/1930-1939/decreto-20158-30-junho-1931536778-republicacao-81246-pe.html

Decree n. 20,465. (1931, October 30 ${ }^{\text {th }}$ ). Reforms the legislation for Retirement and Pension Funds. Retrieved from https://www2. camara.leg.br/legin/fed/decret/1930-1939/decreto-20465-1outubro-1931-500674-publicacaooriginal-1-pe.html

Decree n. 21,033. (1932, February $8^{\text {th }}$ ). Establishes new conditions for the registration of accountants and bookkeepers and makes other arrangements. Retrieved from https://www2. camara.leg.br/legin/fed/decret/1930-1939/decreto-21033-8fevereiro-1932-504263-publicacaooriginal-1-pe.html

Decree n. 22,382. (1933, January $23^{\text {rd }}$ ). Postpones for three month the deadline for enrollment in the exams referred to by art. 55 of decree n. 20,158, of June $30^{\text {th }}$ of 1931 , and suspends for three months the execution of part of the arrangements of art. 74 of the same decree. Retrieved from https://www2.camara. leg.br/legin/fed/decret/1930-1939/decreto-22382-23-janeiro1933-515664-publicacaooriginal-1-pe.html

Decree n. 24,747. (1934, July $\left.14^{\text {th }}\right)$. Creates the Actuarial Department of the Ministry of Labor, Industry, and Commerce and makes other arrangements. Retrieved from https://www2.camara.leg.br/legin/fed/decret/1930-1939/ decreto-24747-14-julho-1934-526846-publicacaooriginal-1pe.html

Decree n. 24,748. (1934, July $14^{\text {th }}$ ). Approves the regulation of the Actuarial Department of the Ministry of Labor, Industry, and Commerce. Retrieved from https://www2.camara.leg.br/legin/ fed/decret/1930-1939/decreto-24748-14-julho-1934-526847republicacao-78639-pe.html

Decree $n$. 294. (1895, September $\left.5^{\text {th }}\right)$. Discusses foreign life insurance companies that operate in Brazil. Retrieved from https://www2.camara.leg.br/legin/fed/decret/1824-1899/ decreto-294-5-setembro-1895-540724-publicacaooriginal41573-pl.html

Decree $n .4$,270. (1901, December $10^{\text {th }}$ ). Regulates the functioning of maritime and land-based national and foreign life insurance companies. Retrieved from https://www2. camara.leg.br/legin/fed/decret/1900-1909/decreto-4270-10dezembro-1901-523118-republicacao-108661-pe.html

Decree n. 4,682. (1923, January $\left.24^{\text {th }}\right)$. Creates, in each one of the railway companies existing in the country, a retirement and pension fund for the respective employees. Retrieved from https://www2.camara.leg.br/legin/fed/decret/1920-1929/ decreto-4682-24-janeiro-1923-538815-publicacaooriginal90368-pl.html

Decree $n .5,109$. (1926, December 20 $\left.0^{\text {th }}\right)$. Extends the regime of legislative decree n. 4,682 , of January $24^{\text {th }}$ of 1923 , to other companies. Retrieved from https://www2.camara.leg.br/legin/ fed/decret/1920-1929/decreto-5109-20-dezembro-1926564656-publicacaooriginal-88603-pl.html

Decree-Law $n .7,988$. (1945, September $\left.22^{\text {nd }}\right)$. Discusses the degree course in economic sciences and in accounting and actuarial sciences. Retrieved from https://www2.camara.leg.br/legin/ fed/declei/1940-1949/decreto-lei-7988-22-setembro-1945417334-publicacaooriginal-1-pe.html

Decree-Law n. 806. (1969, September $\left.4^{\text {th }}\right)$. Discusses the profession of Actuary and makes other arrangements.
Retrieved from https://www2.camara.leg.br/legin/fed/ declei/1940-1949/decreto-lei-7988-22-setembro-1945417334-publicacaooriginal-1-pe.html

Diário Oficial da União (Official Diary of the Union). Editions 1925-1959. Retrieved from https://www.jusbrasil.com.br/ diarios/DOU/

Fundo de reserva para a aposentadoria dos ferroviários (Reserve fund for the retirement of railway workers). (1931, January $\left.25^{\text {th }}\right)$. The state of São Paulo. Retrieved from http://acervo. estadao.com.br

Garcez, B. N. (2004). O Mackenzie: 1870-1960 (2 ${ }^{\text {nd }}$ ed.). São Paulo, SP: Editora Mackenzie.

Gauthier, M. (1932). Contabilidade das empresas de seguros de vida e de capitalização. In Segundo Congresso Brasileiro de Contabilidade (p. 159-175). Rio de Janeiro, RJ

Gomes, Â. M. de C. (2005). A invenção do trabalhismo (3 ${ }^{\text {rd }}$ ed.). Rio de Janeiro, RJ: Editora da Fundação Getúlio Vargas.

Gomes, Â. M. de C. (Coord.) (2007). Ministério do Trabalho: uma história vivida e contada. Rio de Janeiro, RJ: Centro de Pesquisa e Documentação de História Contemporânea.

Hickman, J. (2004). History of actuarial profession. Encyclopedia of Actuarial Science. Retrieved from https://onlinelibrary.wiley. com/doi/abs/10.1002/9780470012505.tah012

Hochman, G., \& Fonseca, C. M. (1999). O que há de novo? Políticas de saúde pública e previdência, 1937-45. In D. Pandolfi (Org.), Repensando o Estado Novo. Rio de Janeiro, RJ: Editora da Fundação Getúlio Vargas.

Instituto Brasileiro de Atuária (Brazilian Actuarial Institute) (IBA). (1944-1945). Revista Brasileira de Atuária, 4(3/4), 83-99.

Instituto Paulista de Contabilidade (São Paulo Accounting Institute). (1925). Regulation on business education. Revista Paulista de Contabilidade, 1(12), 43-47.

Law n. 1,401, of July $31^{\text {st }}$ of 1951. (1951, July $\left.31^{\text {st }}\right)$. Includes, in the economic sciences course, the discipline of General and Brazilian Economic History, and develops the accounting and actuarial sciences course. Retrieved from http://www2. camara.leg.br/legin/fed/lei/1950-1959/lei-1401-31-julho1951-375767-publicacaooriginal-1-pl.html

Loyola, I. (2019). Uma reforma que não reforma. Retrieved from https://www.jornaldocomercio.com/_conteudo/ opiniao/2019/03/673117-uma-reforma-que-nao-reforma.html

Malloy, J. M. (1986). A política da previdência social no Brasil. Rio de Janeiro, RJ: Graal.

Moreira, J. F. (2014). Escola Central: a academia do Largo de São Francisco de Paula que consolidou o ensino de engenharia civil no Brasil (Doctoral Thesis). Universidade Federal do Rio de Janeiro, Rio de Janeiro.

Oliveira, J., \& Teixeira, S. (1989). (Im)previdência social. 60 anos de história da previdência no Brasil ( $2^{\mathrm{a}}$ ed.). Petrópolis, RJ: Vozes.

Peleias, I. R., Silva, G. P. da, Segreti, J. B., \& Chirotto, A. R. (2007). Evolução do ensino da contabilidade no Brasil: uma análise histórica [Special]. Revista Contabilidade \& Finanças, 18, 1932. https://dx.doi.org/10.1590/S1519-70772007000300003

Questões do trabalho. (1930, December 2 $\left.{ }^{\text {nd }}\right)$. Jornal do Brasil, issue 00284. Retrieved from http://memoria.bn.br/ 
DocReader/docreader.aspx?bib=030015_05\&pasta=ano\%20 193\&pesq=\%22 collor $\% 20$ tratou $\% 22$

Ramos, G. S. (2002). Ciência atuarial: a história, o profissional e as relações com a economia, a matemática, o seguro e a previdência. Cadernos de Seguro, 22(115), 7-12.

Reis, J. C. (2000). Escola dos Annales - A inovação em história. Rio de Janeiro, RJ: Paz e Terra.

Setubal, A. C. (1927). Da contabilidade de seguros - Parecer. In Primeiro Congresso Brasileiro de Contabilidade (p. 327-330). Rio de Janeiro, RJ.

Siqueira, A. C. T. (Org.). (2008). A história dos seguros no Brasil. Rio de Janeiro, RJ: Cop.
Soares, S. V., Richartz, F., Voss, B. L., \& Freitas, C. L. (2011) Evolução do currículo de contabilidade no Brasil desde 1809. Revista Catarinense da Ciência Contábil, 10(30), 27 42.

Société de Statistique de Paris (1961). Vie de la société. Journal de la Société de Statistique de Paris, 102(10-12), 273-279.

Souza, N. de J. (2006). O economista: a história da profissão no Brasil. Análise, 17(2), 377-383.

Vianna, O. (1951). Direito do trabalho e democracia social. Rio de Janeiro, RJ: José Olympio.

Vieira, E. A. (2010). Autoritarismo e corporativismo no Brasil ( $3^{\text {rd }}$ ed.). São Paulo, SP: Editora UNESP. 